\title{
Empowering Family Awareness of Cardiovascular Disease in Ngangkrik Hamlet, Sleman Regency
}

\section{Erinda Nurrahma ${ }^{1}$, Ailsa Nur Rahma Apta Widyadhana ${ }^{2}$, Annisa Leny Saraswati ${ }^{3}$, Ave Anugraheni ${ }^{1}$, Muhammad Jourdan Prasetyatama ${ }^{4}$, Emy Huriyati ${ }^{1}$}

\author{
${ }^{1}$ Department of Health Nutrition, Faculty of Medicine, Public Health, and Nursing, Universitas Gadjah Mada, \\ Indonesia \\ ${ }^{2}$ Department of Agricultural Microbiology, Faculty of Agriculture, Universitas Gadjah Mada, Indonesia \\ ${ }^{3}$ Department of Nursing, Faculty of Medicine, Public Health, and Nursing, Universitas Gadjah Mada, \\ Indonesia \\ 4Department of Management, Faculty of Economics and Business, Universitas Gadjah Mada, Indonesia
}

Submitted: August 17 2019 ; Revised: May 25 ${ }^{\text {th }} 2021$; Accepted: June $16^{\text {th }} 2021$

$\begin{array}{ll}\text { Keywords: } & \text { Abstract Cardiovascular disease is the main cause of death worldwide and in } \\ \text { Healthy } & \text { Indonesia. Public awareness and acceptance of preventative cardiovascular } \\ \text { lifestyle } & \text { care are crucial for reducing illness-related morbidity and mortality. As a result, } \\ \text { Heart } & \text { community service is essential for the primary prevention of cardiovascular } \\ \text { Blood } & \text { disease. Between April and July 2019, this community service was undertaken } \\ \text { vessels } & \text { in Ngangkrik Hamlet, Sleman Regency, Yogyakarta Special Region (DIY). } \\ \text { Cardiovascular } & \text { Ngangkrik locals participated in this program in three categories: Bapak Bijak } \\ \text { desease } & \text { (Wise Dads), Ibu Cerdas (Smart Moms), and Pemuda Bijak (Wise Youngsters). } \\ & \begin{array}{l}\text { Five stages comprised this program: planning, informing, preparation, } \\ \text { implementation, and oversight. Lectures/courses, discussions, practice, and } \\ \text { roleplaying were used to implement the materials. To examine participants' } \\ \text { knowledge, the pretest and posttest approach was utilized. The program raised } \\ \text { participants' knowledge and understanding about the prevention and } \\ \text { treatment of cardiovascular disease across all categories. }\end{array}\end{array}$

\section{INTRODUCTION}

Cardiovascular disease is a major public health concern both globally and in Indonesia. This disease is the world's biggest cause of death. Over $30 \%$ of the world's population, or 17.9 million people, died of the disease, with $75 \%$ of deaths occurring in developing countries such as Indonesia (WHO, 2017). Special Region of Yogyakarta (Daerah Istimewa Yogyakarta (DIY)) ranks third in terms of heart disease prevalence, according to the 2018 Basic Health Research (Indonesian Health Ministry, 2018). Without a doubt, the huge number poses a threat to the community's quality of life.

Unhealthy lifestyle choices such as smoking, poor diet, and lethargy all contribute to cardiovascular disease. At least one in every four Indonesians aged ten years or older are active smokers (Indonesian Health Ministry, 2018). The 2014 Indonesian Food Consumption Survey (Survei Konsumsi Makanan Indonesia $(S K M I)$ ) reveals that 52.7 percent of Indonesians eat more than $2000 \mathrm{mg}$ of sodium per day, 26.5 percent ingests more than 67 grams of fat per day, and 4.8 percent consumes more than 50 grams of sugar daily. Consuming sugar, salt, and fat over the prescribed amounts can raise your risk of developing Non-Communicable Diseases (NCDs), including cardiovascular disease (Indonesian Health Ministry, 2017). Over a third of Indonesia's population aged 10 and over are classed as inactive lacking in physical

ISSN 2460-9447 (print), ISSN 2541-5883 (online)

${ }^{*}$ Corresponding author: Erinda Nurrahma

Department of Health Nutrition, Faculty of Medicine, Public Health, and Nursing, Universitas Gadjah Mada, J. Farmako, Sekip Utara, Sinduadi, Mlati, Sleman, DIYogyakarta 55284, Indonesia

Email: erinda.nurrahma@gmail.com 
activities or only engages in physical activities for fewer than 150 minutes each week (Indonesian Health Ministry, 2018).

Cardiovascular disease prevention measures must begin with the individuals, most notably with the adoption of a healthy lifestyle. As a result, everyone has to understand the crucial nature of leading a healthy lifestyle to avoid cardiovascular disease. Additionally, these programs require community support and cooperation to be successful.

The government has implemented a few prevention and promotion programs aiming at reducing morbidity and mortality rates related to cardiovascular disease and other non-communicable diseases. This phase was completed through a type of communitybased health activity known as Integrated Counseling Post (Pos Bimbingan Terpadu (Posbindu)), which focuses on the early detection and control of risk factors under the supervision of Community Health Center (Pusat Kesehatan Masyarakat (Puskesmas)) (Primiyani et al., 2019). Each village is required to have at least one PTM Posbindu capable of reaching all residents in the region aged 15 years or older. Sleman subdistrict currently has Non-Communicable Diseases Integrated Counseling Post (Pos Bimbingan Terpadu Penyakit Tidak Menular (Posbindu PTM)) in each of its sub-districts and intends to expand to every village. However, just a few of Posbindu constructed are selfsustaining. Following Posbindu's establishment, several obstacles were encountered, including the following: cadres were required to act as double agents to implement UKBM; cadres remained highly dependent on officers from Puskesmas, were unable to go independently and required assistance for every activity; and they were unable to target the correct target, such as the healthy population or productive ages.

Ngangkrik Hamlet is located in Triharjo Subdistrict of the Sleman District of Yogyakarta Special Region. The community that serves as the working environment for Sleman Health Center is one of the villages that does not yet have a Posbindu. Residents of Ngangkrik suffered from a significant risk of cardiovascular disease as a result of bad lifestyle choices such as an imbalanced diet high in sugar, salt, and fat, lethargy, and smoking in places. Over $50 \%$ of households in Ngangkrik are estimated to have at least one active smoker. One in every four elderly people, according to data from Posyandu of Ngangkrik Hamlet, has hypertension.

Based on these issues, a community service project was undertaken to increase community awareness and empowerment to prevent and treat cardiovascular disease. This community activity took place in Ngangkrik as part of a Student Creativity Program sponsored by the Ministry of Research, 139 www.jurnal.ugm.ac.id/jpkm
Technology, and Higher Education of the Republic of Indonesia.

Cardiovascular disease is caused by dysfunctional heart and blood vessel function. Cardiovascular disease includes coronary heart disease (CHD), Rheumatic Heart Disease (RHD), congenital heart disease, heart attack, peripheral artery disease, aortic aneurysm, stroke, and hypertension (Mackay and Gensah, 2004). Numerous factors can play a role in the onset of cardiovascular disease. According to the Indonesian Ministry of Health (2014), there are two types of risk factors for cardiovascular disease: those that can be controlled and those that cannot be controlled. Stress, dyslipidemia, diabetes mellitus, hypertension, and an unhealthy lifestyle, which includes poor eating habits, a lack of physical activity, and smoking habits, are all preventable risk factors. While risk factors such as the family history of the disease, age, gender, and obesity are uncontrollable.

A sedentary lifestyle exacerbates cardiovascular disease. Unhealthy eating habits, such as consuming meals high in fat, calories, sodium, and low in fiber, are associated with an increased risk of cardiovascular disease, obesity, type 2 diabetes, and other noncommunicable diseases (Permanasari and Julianti, 2018). Immobility is also associated with an increased risk of cardiovascular and other chronic diseases. Sluggish physical activity levels are a result of sedentary behavior, urbanization or population movement, technological improvements, and modes of transportation. This inactivity can contribute to the body storing an abnormal amount of energy in the form of fat, which can act as a risk factor for chronic diseases such as cardiovascular disease (Febriyanti et al., 2015). Furthermore, smoking is associated with an increased risk of developing cardiovascular disease. According to Lestari et al. (2014), cigarettes containing nicotine can stimulate blood coagulation, hence increasing blood pressure. Furthermore, blood clots can obstruct blood flow to the heart and brain, resulting in coronary heart disease and stroke.

Lifestyle changes are critical for cardiovascular disease prevention. One of them is to make dietary changes. A low-fat diet, a low-carbohydrate diet, a DASH diet, and a Mediterranean diet are all examples of eating patterns that can help prevent cardiovascular disease (Eilat-Adar et al., 2013). The Mediterranean diet is a European diet that emphasizes the consumption of fruits and vegetables, as well as foods high in fat that contain MUFA (Monounsaturated Fatty Acids), such as olive oil and nuts, which act as antioxidants and antiinflammatory agents in the body, thereby decreasing the risk of cardiovascular disease (Anggraini and Labibah, 2016). Increased physical activity is also crucial for the prevention of cardiovascular disease. World Health Organization recommends that persons 
between the ages of 18 and 65 engage in around 150 minutes of moderate physical activity or approximately 75 minutes of intense physical activity each week (WHO, 2018). Moderate physical exercise includes cycling, stair climbing, and rapid walking. While vigorous physical exercise includes, but is not limited to, jogging, swimming, futsal, soccer, and badminton. Smoking must also be avoided if cardiovascular disease is to be avoided. According to the Indonesian Ministry of Health (2017), quitting smoking has many benefits, including maintaining normal blood pressure, increasing oxygen levels in the body, normalizing organ functions such as the heart and lungs, and lowering the risk of chronic diseases such as coronary heart disease (CHD), stroke, and lung cancer.

Cardiovascular disease prevention efforts can be classified into two categories: primary prevention (prevention of cardiovascular disease before it starts) and secondary prevention (prevention of disease severity in those who already have cardiovascular disease). Primary prevention, according to Widodo (2012), might involve routine health tests and a healthy lifestyle that includes nutritious food and appropriate physical activity. While secondary prevention comprises reducing risk factors for disease, including routine physical examinations, laboratory tests, and consulting with a physician. Thus, routine health checkups are crucial for recognizing anomalies in our hearts and blood vessels that may result in cardiovascular disease.

\section{METHODS}

\subsection{Subject and program site}

This community service was conducted in Ngangkrik Hamlet from April to July 2019. Ngangkrik Hamlet is a village in Trihajo Urban Village, Sleman Subdistrict, Sleman Regency, Yogyakarta Special Region. This village consists of 625 Heads of Families (Kepala Keluarga (KK)) with 12 neighborhood units (Rukun Tetangga (RT)) and 4 community units (Rukun Warga (RW)). The population of Ngangkrik Hamlet was roughly 2,000, with 1,024 men and 976 women. Residents of Ngangkrik earned between low and middle incomes, with the majority working as casual laborers, farmers, self-employed individuals, traders, and housewives. The majority of citizens of Ngangkrik had completed their high school education (Sekolah Menengah Atas (SMA)). This settlement did not have a PTM Posbindu. Then again, harmful habits such as an imbalanced diet high in sugar, salt, and fat, a lack of physical activity, and a smoking habit were commonly encountered among the residents.

This program enrolled 26 service members in three categories: eight dads as Wise Dads (Dare to Avoid Cigarette Smoking), eight moms as Smart Moms
(Wise in Managing Domestic Health), and 10 youngsters as Wise Youngsters (Ready to Prevent and Treat Cardiovascular Disease). A stratified sampling strategy was used to choose participants for this community service initiative. Participants were recruited based on a variety of characteristics, including residency, a history of cardiovascular sickness and/or a family history of cardiovascular disease, and a willingness to participate in community service programs. The program's goal was to train cadres who would contribute to the prevention and treatment of cardiovascular disease in their community and would commence the development of PTM Posbindu, which would operate independently and sustainably in the area.

Numerous steps were involved in this form of community service, including planning, knowledge sharing, preparation, implementation, and control. The community was involved at every stage of the action. The planning process included meetings with Ngangkrik's officials and youth to determine the program's schedule and specifics. The knowledge sharing stage was the stage during which the program was offered to the community to elicit active participation. Preparation necessitated the procurement of tools and resources, as well as the development of instructional media. The implementation phase encompassed cadres development and training, public education, (Peduli Penyakit Kardiovaskular untuk Masyarakat (Perikardium)) card distribution, and data gathering. The control phase includes monitoring and assessment.

\subsection{Met hod of program implementation}

Five stages comprised the implementation of this program: planning, informing, preparation, implementation, and control.

\subsubsection{Planning}

activities. Discussions with the village head and the youth leader of Ngangkrik were held to ascertain the community's concerns, its capabilities, and any potential hurdles to program implementation that might arise in the field. Continuing dialogues, program implementation planning activities were conducted to determine the timing and location of implementation to ensure that the program ran smoothly and following community expectations.

\subsubsection{Informing the program}

The program was then informed to all members of the Ngangkrik community via community meetings, Family Welfare Empowerment (Pemberdayaan Kesejahteraan Keluarga (PKK)) meetings, and meetings with the village's youngsters. This stage sparked interest in the community in supporting and even participating in this program. 


\subsection{Preparation}

Preparations included the procurement of tools and resources, as well as the creation of instructional media. The program's implementation team, which consisted of students from the Health Nutrition and the prevention of non-communicable diseases. The learning media were developed following cardiovascular disease prevention and balanced nutrition guidelines taken from the World Health Organization, Ministry of Health, and scientific journals. Tool and material procurement involved the acquisition of medical equipment, such as a sphygmomanometer, a microtoise, scales, and a tapeline. Additionally, this program required the acquisition of public posters, plant seeds, healthy lifestyle checklists, cardiopulmonary resuscitation checklists, and posters for standard operating procedures for cardiac arrest, heart attack, and stroke, among other items. The creation of instructional media aided in the delivery of material necessary for the program's viability.

Modules, X-banner-shaped banners, movies, and brochures were employed as instructional mediums. This program included two modules: one having guidelines for balanced nutrition and a guide to making healthy food for the activities of Smart Moms, and the other containing guidelines for health checks as early detection of cardiovascular disease for the activities of Wise Youngsters. The media in the form of posters in the shape of X-banners were divided into two sections: posters about the dangers of smoking and the importance of increased physical activities for Wise Dads' programs, and posters about balanced dietary guidelines for Smart Moms' activities. Besides, one educational video was created to provide explanations and demonstrations for the Wise Youngsters' activities on first aid for cardiac illness. Pamphlets with directions for organic vegetable production and the synthesis of biological insecticides were compiled in support of Wise Dads' activities.

\subsubsection{Implementation}

The program was implemented through cadre recruitment and training, community education, the distribution of Perikardium cards, and the compilation of health data reports. Cadres were formed by selecting
Nursing study program and students from the Agronomy study program, created educational media. Additionally, the educational media had been edited by physicians and lecturers who had previously participated in community service projects focused on three family components: dads, moms, and youngsters. Three cadres were formed: Wise Dads (Dare to Avoid Cigarette Smoking), Smart Moms (Smart in Managing Domestic Health), and Wise Youngsters (Ready to Prevent and Treat Cardiovascular Disease). Kridorescue was the name given to Wise Youngsters. Cadre training took place on Sundays of various weeks for each cadre group's activity. The trainers were selected from the program's team of students with health-related educational backgrounds.

The Wise Dads' training included instructional activities regarding the harms of cigarette smoke, offering motivations and effective methods for quitting, and as well as fostering a common commitment to not smoke during community forums. The topic was taught via lectures and conversations, both of which incorporated X-banner media. Furthermore, training in organic vegetable gardening and the synthesis of biological insecticides from papaya leaves was conducted, which aided in enhancing the community's physical activity. This training was conducted using the demonstration technique, followed by participant practice.

The Smart Moms workshop consisted of a series of activities aimed at educating participants about cardiovascular disease and the need of living a healthy lifestyle that included balanced nutritional food, adequate physical activity, and quitting smoking. Courses were used to impart education, which was supplemented with media in the form of X-banner posters and modules. Furthermore, the moms were instructed in serving nutritious meals through demonstration methods and practices such as cooking healthy snacks that are low in sugar, salt, and fat and high in antioxidants and fiber. To improve the moms' physical activity, they were also taught how to grow organic vegetables using a brochure comprising a threemonth vegetable growing cycle as a guide. Later on, the family can use organic vegetables to supplement their diet. Figure 1 depicts the activity stages for the Wise Dads and Smart Moms cadres.

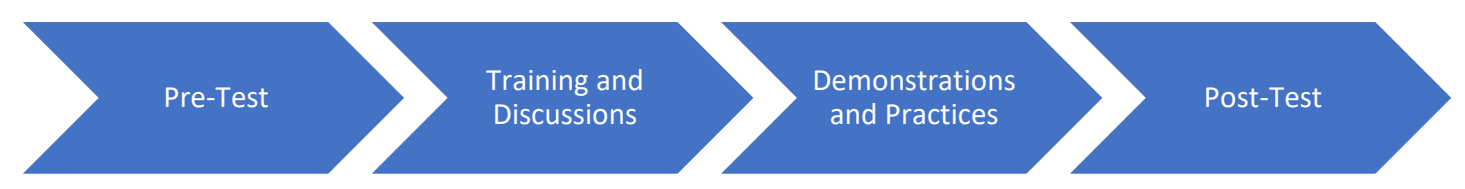

Figure 1. Activities in Wise Dads and Smart Moms Trainings 
The Wise Youngsters cadres received training through lectures on healthy lifestyles and cardiovascular illness, as well as demonstrations of first aid procedures for cardiac arrest, heart attacks, and strokes via first aid videos. The activity was then followed by a reenactment of cardiac resuscitation. Other than that, the youngsters received additional training on performing routine health checks to detect early cardiovascular disease. Simple health examination training was delivered in the form of digitally measuring blood pressure, weighing and measuring height, calculating body mass index, measuring waist circumference and hip circumference, and interpreting examination results through demonstration and roleplay. Figure 2 depicts the activity stages for Wise Youngsters cadres (Kridorescue).

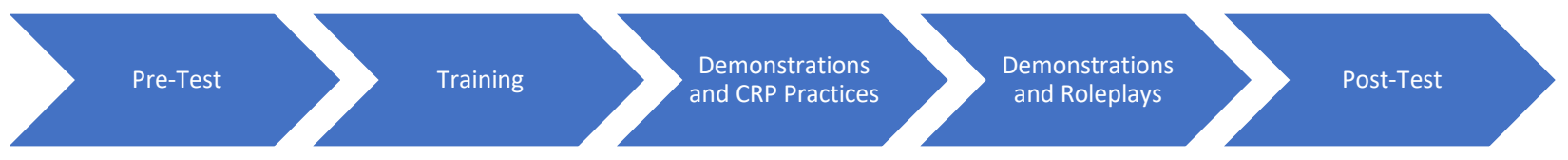

Figure 2. Activities in Wise Youngsters training (Kridorescue)

The general public was coached by the placement of instructional posters in strategic locations such as patrol points. Subsequently, standard operating procedures for first aid in the event of cardiac arrest, heart attack, or stroke were taught. The final stage of execution was the distribution of Perikardium cards to the residents of Ngangkrik. The Perikardium card is a card that contains the results of a public health examination, and a risk chart is used to determine the risk of developing cardiovascular disease for each individual. The results of the health exams were subsequently summarized and forwarded to Sleman Health Center personnel for follow-up.

\subsection{Control}

The control stage was divided into three components: monitoring, evaluation, and collaboration with Puskesmas. Monitoring operations were designed to ascertain the barriers that cadres encounter in carrying out their responsibilities. These attempts were conducted through one-month follow-up interviews with cadres to ascertain the challenges they encounter. Then, as an improvement undertaking, the best solution to these impediments was sought. Further, evaluation activities were conducted to determine whether major changes occur in partners following the program's implementation. To detect changes in cadres' level of knowledge, evaluation activities included administering a pre-test at the start of the program and a post-test at the conclusion. Finally, there was a partnership with Puskesmas. This collaborative activity was conducted to monitor the results of health examinations. Individuals at a high risk of cardiovascular disease might take early action to avoid aggravating their health condition.

\subsection{Data Analis}

The objective of this community service was to improve participants' comprehension of the distribution of materials and training. The researchers used the Wilcoxon signed-rank test to examine the effect of offering educational materials and training on community service to enhance public awareness of cardiovascular disease. If the p-value for the statistical test is less than 0.05 , the alternative hypothesis will be accepted, and the statistical test results can be considered significant.

\subsection{Program Evaluation Methods}

Program assessment is necessary to identify any impediments or difficulties that need to be addressed and resolved to build a sustainable program. The technique of program assessment consisted of various components, including pre-and post-testing, process checklists, direct practice in the community, and questionnaires for program evaluation. Pre- and posttests were used to assess the community's competence and knowledge before and following the implementation of this program. A process checklist was a set of steps to do to facilitate the community's practice of an activity, such as the cardiac resuscitation checklist procedure for children. Direct practice activities in the community were designed to help people comprehend and develop their abilities by putting what they have learned into practice. Meanwhile, the program assessment questionnaire was a questionnaire that the community completed determining if the program was being implemented following their expectations. This program assessment questionnaire was designed to enable follow-up activities in the event of program implementation setbacks or difficulties.

\section{RESULT AND DISCUSSION}

The local community's enthusiasm was palpable, and they remained amicable throughout the program. However, not all invited individuals were able to attend, 
resulting in an 81.25 percent participation rate. Participants in this exercise were eight cadres of Wise Dads, eight cadres of Smart Moms, and ten cadres of chosen. The activity was targeted at RT 01 since the organization of the head of the household was more involved and these dads had a regular monthly gathering. Meanwhile, the Smart Moms activity drew participants from selected representatives of moms from each RT. Each of twelve RTs in Ngangkrik was requested to send one mom to participate in the program, but only eight RTs did so. Wise Youngsters activity was chosen for 10 youngsters based on the criteria, with a ratio of three males to seven females.

Each category had two training sessions over two days. On the first day, participants took a pre-test to establish their baseline knowledge. After one week, on
Wise Youngsters, for a total of twenty-six participants. Wise Dads program drew participants from RT 01, and eight individuals who met the requirements were the second day of training, participants were given a post-test after the training session. The pre-and post-test questions were tailored to the material from each cadre group, ensuring that each cadre group got a unique preand post-test questionnaire.

In the dads' group, a comparison of pre-and posttest scores revealed that $96 \%$ of participants had a rise in post-test scores, while $4 \%$ experienced no change in ratings. Meanwhile, in the youngsters and mom categories, all participants experienced an increase in post-test scores. Table 1 summarizes the average outcomes of the pre-and post-test training.

Table 1. Average pre-test and post-test scores

\begin{tabular}{lccc}
\hline \multicolumn{1}{c}{ Category } & Pre-test Mean Score & Post-test Mean Score & Average Delta Increase \\
\hline Wise Dads & $48.35 \pm 9.74$ & $78.75 \pm 18.85$ & $30.39 \pm 20.79$ \\
Smart Moms & $43.15 \pm 13.73$ & $76.25 \pm 17.68$ & $33.10 \pm 20.42$ \\
Wise Youngsters & $57.50 \pm 15.14$ & $75 \pm 5.27$ & $17.5 \pm 13.18$ \\
Total & $50.27 \pm 14.15$ & $76.54 \pm 14.12$ & $26.27 \pm 18.75$
\end{tabular}

The Wilcoxon signed-rank test revealed that the average negative difference between post-test and pretest scores for the Wise Dads group was 0, while the average positive difference between post-test and pretest scores was 4.5, with a p-value of 0.012. Thus, in the Wise Dads group, there was an increase in knowledge and awareness of measures to prevent and cure cardiovascular disease. On the other hand, the results indicated that the average negative difference between post-test and pre-test scores for the Smart Moms category was 0 , the average positive difference between post-test and pre-test scores for this category was 4 , and the $\mathrm{p}$-value for this category was 0.018 , denoting that there was an increase in knowledge and understanding regarding efforts to prevent and treat cardiovascular disease in the Smart Moms category. Additionally, the average negative difference between post-test and pretest scores for the Wise Youngsters category was 0 , the average positive difference between post-test and pretest scores for the Wise Youngsters category was 5.5, and the p-value was 0.005 , indicating that there was an increase in knowledge and understanding regarding efforts to prevent and treat cardiovascular disease.

Furthermore, an assessment was performed during this activity to determine the program's effect from the participants' viewpoint. The assessment was conducted via the completion of a questionnaire that contained questions about the participants' knowledge and comprehension, the usefulness of the content, and the correctness of the training technique. The activity evaluation findings are depicted in Figure 1, Figure 2, Figure 3, and Figure 4.

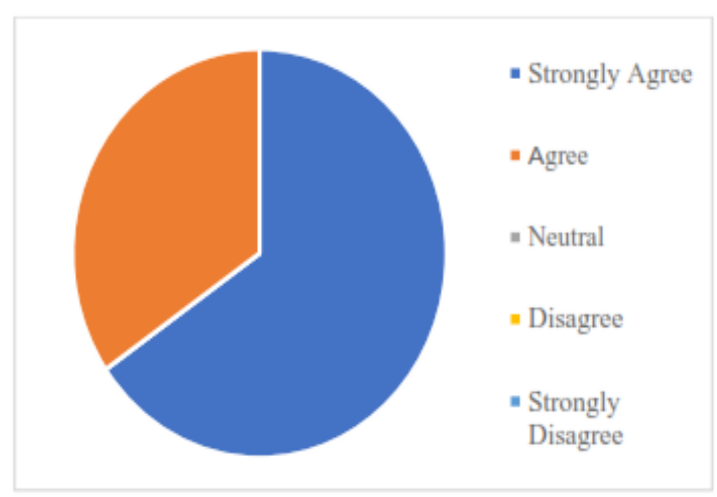

Figure 3. Responses to the question of whether participants acquire new knowledge as a result of participating in this program

As seen in the graph above, when the Perikardium program was completed, as many as $65 \%$ of respondents chose strongly agree and $35 \%$ chose to agree, indicating that all participants expressed positive responses to the program's benefits. 


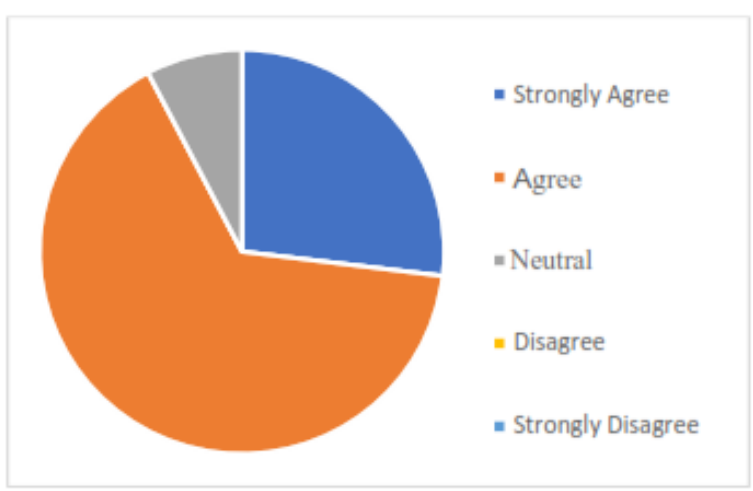

Figure 4. Responses to questions about the effectiveness of the training methods employed

Referring to the graph above, when Perikardium program was completed, up to $27 \%$ of respondents answered strongly agree, while $65 \%$ and $8 \%$ respectively responded agree and neutral. This demonstrates that the strategy we used was quite suitable for the program and the material had been delivered.

Participants were required to apply the knowledge learned through this community service program in their daily lives. As a result, participants needed to be able to comprehend the information presented during the training. After participants apply the acquired knowledge, the community's risk of cardiovascular disease could be reduced. Additionally, if the public can detect the symptoms of a heart attack, cardiac arrest, or stroke and is rapid in delivering assistance, the occurrence of fatality will be reduced.

According to the results of the pre-and post-tests, the training provided to all participants may have increased their knowledge and awareness of cardiovascular disease and the application of a healthy lifestyle. After the programs were introduced, there was an increase in knowledge and awareness across all categories, including Wise Dads, Smart Moms, and Wise Youngsters.

According to the findings of the procedure checklist review, $60 \%$ of Wise Youngsters were able to perform CPR according to the protocol. Meanwhile, when Wise Youngsters cadres were deployed in simple health services, they were able to serve the community well through direct practice.

Additionally, participants were given a questionnaire consisting of five questions to evaluate the program that had been implemented. The first question concerned whether or not participants gained new knowledge as a result of this training. Following that, it was discovered that all participants thought they had received new knowledge about cardiovascular disease and maintaining a healthy lifestyle. The second question assessed participants' ability to comprehend the material delivered. According to the participants' responses to these questions, it was determined that the majority of participants understood the training material. The third question inquired as to the usefulness of the material delivered to the participants. Then, it was determined that all participants agreed on the material's usefulness. The final question concerned the suitability of the approach used to train participants, and it was discovered that nearly all participants agreed that the method used was appropriate for use in this program.

The strategy employed is one way to boost trainees' knowledge and comprehension. This program will include a variety of modalities, including lectures, discussion sessions, activities, and role-plays. The lecture technique has the advantage of making it easy for the speaker to manage the participants and to present the content. The disadvantage of this method is that it is difficult for the speaker to gauge participant interest in the subject delivered, using the lecture method for an extended time becomes tedious, and listeners tend to remain inactive (Widayati, 2004).

The second method was discussion. Among the benefits of the discussion, the approach was that it acclimates participants to conducting debates, adds insight, and fosters an attitude of respect for the viewpoints of others. The drawbacks of this method included that the debate veered off subject, the information gathered by participants was more limited, and the process took longer (Widayati, 2004).

The third way, referred to as the practical method. The advantages of this strategy were that it increased participants' trust and confidence in the material presented. Apart from that, this strategy enabled participants to gain a better understanding of the practical applications of the delivered materials. The method's drawback was that it needed participants' persistence, thoroughness, and fortitude. Moreover, the results gained were not always as intended (Widayati, 2004).

The final technique was a role -lay. The roleplaying strategy offered several advantages, such as drawing participants' attention and creating a more vibrant atmosphere. Additionally, it piqued participants' curiosity in taking part in a training process (Kartini, 2007). The disadvantage of this strategy was that it tended to make participants passive if used at the start of the program (Baroroh, 2011). In practice, this procedure likewise was time-consuming.

Furthermore, learning media were employed to facilitate the delivery of material and to support the comprehension of training participants. Modules, Xbanner-shaped banners, videos, and pamphlets were employed as instructional media in this program. The modules were incorporated into Smart Moms activity that focused on balanced nutrition. Module-based resources were also used in Wise Youngsters activity, 
which included basic health check procedures. Xbanner posters were used to promote activities across all categories. The posters featured infographics on cardiovascular disease, the hazards of smoking, and the necessity of physical activity. Meanwhile, Wise Youngsters were trained using movies depicting cardiopulmonary resuscitation methods. Pamphlets offering advice on how to grow organic veggies and produce biological pesticides were the last kind of educational media.

The benefits of a comprehensive program were also established since it included not only dads and moms but also youngsters, allowing for optimal implementation of a healthy lifestyle according to each role in the family.

\section{CONCLUSIONS}

Perikardium training program can improve participants' knowledge and comprehension of efforts to prevent and treat cardiovascular disease from the categories of Wise Dads, Smart Moms, and Wise Youngsters. Following the implementation of this program, it is intended that the community's risk of cardiovascular disease will be lowered by promoting a healthy lifestyle. Commitment and cooperation from the community are also critical for the successful implementation of a sustainable program. Additionally, this program has the potential to be re-implemented more extensively in other sectors.

\section{REFERENCES}

Anggraini, D. I., \& Labibah, Z. (2016). Diet Mediterania dan Manfaatnya terhadap Kesehatan Jantung dan Kardiovaskular. Jurnal Majority, 5(3), 188-193.

Baroroh, K. (2011). Upaya Meningkatkan Nilai-Nilai Karakter Peserta Didik Melalui Penerapan Metode Role Playing. Jurnal Ekonomi \& Pendidikan, 8(2), 149-163.

Cardiovascular diseases (CVDs). (2017). Terdapat di https://www.who.int/news-room/factsheets/detail/cardiovascular-diseases-(cvds).

Eilat-Adar, S., Sinai, T., Yosefy, C., \& Henkin, Y. (2013). Nutritional recommendations for cardiovascular disease prevention. Nutrients, 5(9), 3646-3683.

Febriyanti, N. K., Adiputra, I. N., \& Sutadarma, I. W. G. (2015). Hubungan indeks massa tubuh dan aktivitas fisik terhadap daya tahan kardiovaskular pada mahasiswa Fakultas Kedokteran Universitas Udayana. Erepo Unud, 831, 1-14.

Kartini, T. (2007). Penggunaan Metode Role Playing untuk Meningkatkan Minat Siswa dalam Pembelajaran Pengetahuan Sosial di Kelas V SDN Cileunyi I Kecamatan Cileunyi Kabupaten Bandung. Jurnal Pendidikan Dasar, 8, 1-5.

Kemenkes RI. (2014). Pusat Data dan Informasi Kementerian Kesehatan RI Situasi Kesehatan
Jantung. Terdapat di http://www.depkes.go.id/download.php?file=do wnload/pusdatin/info datin/infodatinjantung.pdf.

Kemenkes RI. (2017). Penyakit Jantung Penyebab Kematian Tertinggi, Kemenkes Ingatkan Cerdik. Jakarta, Indonesia : Biro Komunikasi dan Pelayanan Masyarakat Kementerian Kesehatan RI.

Kemenkes RI. (2018). Riset Kesehatan Dasar. Jakarta : Kementerian Kesehatan Republik Indonesia Badan Penelitian dan Pengembangan Kesehatan.

Kementerian Kesehatan Republik Indonesia. (2017). Hidup Sehat Tanpa Rokok. Terdapat di http://p2ptm.kemkes.go.id/uploads/VHcrbkVobj RzUDN3UCs4eUJ0dVBndz09/2017/11/Hidup_ Sehat_Tanpa_Rokok.pdf.

Lestari, E. S., Saraswati, L. D., \& Setyawan, H. (2014). Faktor Risiko Penyakit Kardiovaskuler (Studi Pada Mahasiswa Perokok Fakultas Teknik Jurusan Mesin Universitas Diponegoro Semarang). Jurnal Kesehatan Masyarakat, 2(1), $67-74$

Mackay, J., \& Mensah, G. A. (2004). The atlas of heart disease and stroke. World Health Organization.

Permanasari, Y., \& Julianti, E. D. (2018). Pola Konsumsi dan Gaya Hidup Kaitannya dengan Kejadian Penyakit Kardiovaskuler di Indonesia. Penelitian Gizi dan Makanan (The Journal of Nutrition and Food Research), 41(2), 113-123.

Peta Jumlah Posbindu PTM. (2017). Terdapat di http://www.p2ptm.kemkes.go.id/profilp2ptm/daftar-informasi-publik/peta-jumlahposbindu-ptm

Primiyani, Y., Masrul, M., \& Hardisman, H. (2019). Analisis Pelaksanaan Program Pos Pembinaan Terpadu Penyakit Tidak Menular di Kota Solok. Jurnal Kesehatan Andalas, 8(2), 399406.

Widayati, A. (2004). Metode Mengajar sebagai Strategi dalam Mencapai Tujuan Belajar Mengajar. Jurnal Pendidikan Akuntansi Indonesia, 3(1), 66-70

Widodo, A. (2012). Upaya Perawat dalam Promosi Kesehatan untuk Pencegahan Penyakit Jantung. Surakarta : Universitas Muhammadiyah Surakarta

World Health Organization. (2018). Physical Activity. Terdapat di https://www.who.int/newsroom/fact-sheets/detail/physical-activity. 